\title{
The Australian Conference of Economists at 40: The State It's In
}

\author{
Alex Millmow ${ }^{1}$
}

\section{Foundation}

It was 1970. It was the Age of Aquarius. The Boeing 747 was introduced into intercontinental service. In Australia, the Federal Treasurer, Les Bury, began to notice that inflation and unemployment were rising simultaneously. And Australian students began studying economics using a localised adaptation of Samuelson's classic textbook.

Something unusual, too, was stirring at the University of Melbourne. It was there that the first Conference of Australian and New Zealand Economists would take place. The Conference would arise from the feeling that the Australian economics profession 'had reached a state of development where a regular meeting was needed for technical discussion'. ${ }^{2}$ Indeed, the new decade would see a remarkable flowering of the Australian economic talent. Names like Corden, Dixon, Groenewegen, Gregory, Gruen, Harcourt, Hogan, Kemp, Nevile, Pagan, Pincus, Porter and Snape would become famous. Each held a depth of loyalty to the Economic Society. They were also committed to the idea of an annual conference as a form of branding for the profession.

\footnotetext{
1 University of Ballarat, a.millmow@ballarat.edu.au. The author is the President of the History of Economic Thought Society of Australia. He has attended 15 ACEs, and delivered papers at 10. The author must thank many people who forwarded old Conference brochures or rendered their vivid memories of Conferences. They are: Peter Abelson, Harry Bloch, Harry Clarke, William Coleman, Owen Covick, Max Corden, Dietrich Fausten, Richard Garner, Peter Groenewegen, Geoff Harcourt, John Lodewijks, John Madden, Terry Maidment, John Nevile, Neville Norman, Jonathan Pincus, Michael Potter, Michael Schneider, Bill Schworm, Martin Shanahan, David Spiers, Jackie Tuck, Shann Turnbull, Steven Turnovsky and Ross Williams. The author also thanks the editing of Amanda Maclean.

Most of the archival material necessary to write this paper is held in the University of Melbourne Archives, where the records of the Victorian branch of the Economic Society of Australia are kept. Some further Economic Society matters were found in the Prest papers and the Downing papers kept in the same archive. The adjoining Baillieu Library also has the papers from the fourth to the twenty-second Conference of Economists on microfiche. However, within this set, there are years missing (1989 and 1991) and one or two other years have an incomplete set of the papers given. Jane Oldroyd kindly allowed the author to examine the remaining records of the NSW Branch of the Economic Society.

The paper has been commissioned and supported by the ACT Branch of the Economic Society of Australia, to mark the occasion of the fortieth Australian Conference of Economists. All opinions and errors are the author's.
}

2 Australian Financial Review, 25 May 1970. 
The Conference of Economists, as it was to become known, would be similar to its American and British counterparts. Until that time, Australasian economists had met as a group under Section 24 of the Australian and New Zealand Association for the Advancement of Science (ANZAAS). ANZAAS welcomed economists into its fold (some economists gave papers at the 1970 ANZAAS held in Port Moresby), and conducted an annual Giblin Lecture (named after one of the founding fathers of Australian economics). ${ }^{3}$ But Robert Scott, the honorary National Secretary of the Economic Society, voiced the sentiment that there was a need for a sharper difference in focus between ACE and ANZAAS, where Australian economists had been giving papers since the 1920s. The latter was an opportunity where economists presented their views to non-economists, while a conference of economists would provide an opportunity for members of the economics profession to talk more technically to one another. In the event, ANZAAS was to cede the field to the new conference: by 1984, the organizer of the fifty-fourth ANZAAS informed the Economic Society that there were very few papers being offered to ANZAAS, and that he was now reliant on invited speakers. ${ }^{4}$ As we shall see, the ACE has ironically suffered a similar process.

The inaugural 1970 Conference was born in the wake of the approval by the Central Council of the Economic Society of Australia and New Zealand of a proposal by the Victorian Branch that 'annual or other regular conferences should be held, separate from and additional to the periodic meetings which take place at the ANZAAS meetings' (Scott 1990: 47). The Victorian Branch had been running day-long autumn forums on economic policy-related issues since 1958, and the New South Wales Branch had been running winter schools even longer. But this new event would be something grander, showcasing Australian academic economic research. And long before the revolutions in communication technology, this Conference would be an opportunity to network and convey research to other specialists.

Organised by Norman Fisher, the first Australian Conference of Economists (ACE) was held at the University of Melbourne over three days, 27-29 May 1970. Interestingly, three of the figures on the committee organising the Conference were not from academe but the private sector. The Conference comprised a collection of 30 high-quality papers from various Australasian economists including Dean Terrell, John Nevile and Adrian Pagan. Here, econometrics made a strong debut with papers (distributed in advance of the Conference) that reflected the latest econometric techniques from abroad. The ACE proved to be a

3 During the mid-seventies the key architect of the Economic Society of Australia, Douglas Copland, also had an oration named after him. However, it was discontinued after the Committee of Economic Development of Australia (another institution which Copland had founded) established a Copland Lecture series. Similarly, after the ANZAAS Giblin Lecture had become defunct, the Tasmanian Branch of the Economic Society and the School of Economics and Finance revived it in 1996.

4 A. J. Kaspura to B. Jordan, 22 March 1984, ESA Victorian Branch UMA. 
'resounding success' with the 290 delegates drawn from universities, businesses and government. Interestingly, the revelry came before the toil; the Conference Dinner, which was booked out with 185 attendees, was on the first night, before any papers were presented. The first after-dinner speaker was the redoubtable Colin Clark.

On the following morning, the inaugural ACE got down to business. The first offering reflected the fashion of the age, a paper on 'Indicative Planning: Recent New Zealand experience', given by A. R. Low from the Reserve Bank of New Zealand, that was published in the June issue of the Australian Economic Review (things were quicker then). ${ }^{5}$ There followed three concurrent sessions on rural economies, macroeconomic analysis and seasonal adjustment. Thus, even from the first Conference economists had to practise what they preach - efficient choice. After lunch came two concurrent sessions: one on the teaching of university economics; the other on land economics. In the first session, Michael Schneider spoke about the new Bachelor of Economics at La Trobe University.

Some of the contributors who graced that first Conference are still alive, and some are still actively researching — names such as Gregory, Harcourt, Ironmonger, Nevile, Norton, Pagan, Sampson, Schneider, Terrell, Tisdell and Wallace. There was a unanimous decision taken at the end of the function to hold another Conference in Sydney the following year. The success of the second ACE, held at the University of Sydney, supported the view that Australian economics had reached a state of development where regular annual meetings were needed for technical discussion.

\section{Function}

In the first decade of the Conferences, there was strict control over what submissions were to be presented.

\section{Submission quality}

Economic Society members deemed from the outset that the Conference should satisfy three criteria. First, that there would be a collection of papers reflecting the interests of Economic Society members; second, that the papers were circulated beforehand; and third, that there be enough time for discussion.

5 While a New Zealander had launched the proceedings of the inaugural Conference, the New Zealand component of the operation quickly faded and the Conference of Economists was soon an exclusively Australian undertaking. The high cost of Trans-Tasman airfares precluded more New Zealanders from attending the early Conferences. 
Invitations for submissions were sent to university economics departments. There would be no guarantee, however, that all submitted papers would be accepted. The organisers of the fourth ACE, held at the ANU, for instance, invited submissions but made it clear that 'those papers chosen for presentation at the Conference will be selected by the programme subcommittee on the basis of merit, general interest and originality of research content'. At the fifth Conference, held at the University of Queensland, some 120 papers were submitted but only 80 were accepted for presentation. The issue of the 'variable' quality of papers was first raised in 1978 by Peter Groenewegen and Frank Collins in their review of the seventh ACE, held at Macquarie University. ${ }^{6}$ They concluded that refereeing would be time-consuming, and that it was hard to judge a paper's suitability by merely reading an abstract. One committee member suggested that a submission fee might eliminate 'frivolous' papers. The committee also noted that the Society's commitment to hold annual Conferences would probably mean a reduction in the quality of subsequent papers.

The matter resurfaced at the tenth ACE, held at the ANU, where more than 100 papers were presented. The organising secretary for the Conference, Lee Martin (of the Industries Assistance Commission), told the Central Council that he had some qualms about the quality of the papers given. He urged that a two-tier format be considered, with some papers being refereed while others were submitted without such scrutiny. He also proposed the commissioning of keynote papers from celebrated speakers (Scott 1990: 61). Max Corden disagreed, but did like the proposal to have specialist speakers, urging the Central Council to consider having six or seven invited speakers give keynote addresses pertaining to the theme of the Conference.

The issue of the quality of papers resurfaced again after the 2003 ACE. There, 181 papers were presented and it seemed to some present that quantity, not quality, was the goal, and there were 'widely perceived ... problems in content and organisation'. ${ }^{7}$ Just as sponsors of the Conference were questioning the quality of some of the submissions and the value in underwriting the event, so too were academics asking what they learned by attending. There were concerns expressed not only about the number of papers but also the huge number of concurrent sessions and low attendance per session - surely the dread fear for any presenter. Following disquiet among sponsors and participants alike, these matters were raised at the Central Council by the President of the NSW Branch, Nigel Stapledon. ${ }^{8}$ The Central Council acted quickly and it was agreed that from 2004 submitted papers would be subject to a 'light refereeing' process to ensure

6 'Programme Committee Final Report and Conference Evaluation of the 7th Conference of Economists', 3 April 1979, ESA Papers, UMA.

7 Economic Society of Australia files, Victoria Branch, UMA.

8 Minutes of the Central Council of the Economic Society of Australia, 31 March 2004, UMA. 
the ongoing reputation of ACE, which was considered a necessary condition for receiving annual funding from several leading institutions. Refereeing on submissions began in earnest in 2004: of some 305 papers submitted, 105 were rejected and 32 withdrawn.

There has been the odd free spirit or maverick whose paper, somehow or other, passed the gatekeepers. One humorous case was that of a Sydney-based data processor who presented two papers at two different Conferences eight years apart but, on both occasions, his contributions left the audience unmoved, perhaps mystified. He took the matter up in a letter to the Council of the NSW Branch of the Economic Society:

My disappointment dates back to 1978 when I presented a paper to the Seventh Conference of Economists. This paper was obviously on the right track towards solving the problems of inflation and unemployment though it did not get there in certain respects. Yet no senior economist showed any interest or offered any help. By 1986 I had 'perfected' the solution and presented it in a paper at the 15th Conference of Economists. Again no senior attendance at the paper, and no response from anyone although several showed some interest and promised to let me have some comments. For a paper that promised a guaranteed solution to inflation and trade cycle unemployment in Australia's economic predicament, I think that this was disgraceful - in fact a dereliction of duty on part of the Society.

The complainant threatened to take the Economic Society to court unless the President of the NSW Branch distributed the paper to members of the Council. This he subsequently undertook but no comment was forthcoming from Council members. ${ }^{9}$

\section{Conference themes and controversies}

One of the ACE's main purposes has been to canvass and reflect upon the economic challenges facing the Australian economy. Speakers from all over the globe - and from academic, government, business and not-for-profit sectors of Australia - would discuss their research findings on contemporary policy issues facing Australia and the world, and enunciate new ideas on how better to understand and predict the economic decisions.

The 1970s was a poor decade in terms of macroeconomic performance; and although the 1980s fared little better, some important economic reforms were undertaken, towards which the Conference could play a significant part.

9 A. B. Jacobs to President of the NSW Branch of the ESA, 18 April 1987, NSW Branch Papers. 
Economists felt it was their duty to point out imperfections in both scales of economic management. Apart from grappling with the scourge of stagflation, economists exposed the costs of tariff assistance and pushed for greater trade liberalisation for the Australian economy. (Policy advocacy was nothing new for Australian economists: in June 1930 economists at the ANZAAS conference prepared and issued a memorandum enlightening Australians of the dire state of the economy.)

The third ACE, held in Adelaide in 1973 and attracting 60 papers compressed into three days, was book-ended by a Conference Dinner on the Monday evening (with an after-dinner speech by Peter Karmel), and an enjoyable tour of the Barossa Valley on the Friday. Among the plenary offerings were Bruce McFarlane on 'The Swedish School'; Bob Gregory and Peter Sheehan on 'The cyclical behaviour of the Australian labour market'; and Peter Groenewegen on 'The feasibility of a net worth tax'.

The following year, ACE met at the ANU, with 45 papers presented. Alan Fels presented a paper on the Prices Justification Tribunal; David Clark had a paper on economic growth; while Colin Clark spoke on inflation and declining profits. Geoff Harcourt presented a paper on the aftermath of the 'Cambridge vs. Cambridge' capital theory controversies.

In 1975, the economists gathered at the University of Queensland, where some 80 papers were presented. Gavin Butler and Frank Stilwell spoke on the teaching of political economy at Sydney University, but did not discuss the controversy of establishing PE courses there. Chris Caton and Chris Higgins gave a paper on the Treasury's economic modelling; Richard Snape spoke on property rights and rent seeking; Jonathan Pincus and Michael Porter gave a paper on the assignment principle and social welfare; and Yew-Kwang Ng deliberated on the Benthamite social welfare function.

After slipping a year, the sixth ACE took place at Hobart in May 1977, where Peter Dixon and his team gave papers on the Orani model. In August of the following year, Macquarie University hosted its one and only Conference on its campus at Ryde. There were 419 registrants, with just one plenary session per day. The eccentric John Blatt, a professor of mathematics at the UNSW, gave a paper on 'The Utility of Being Hanged on the Gallows', a satirical piece on the logical content of contemporary utility theory as used in welfare economics. The organising committee held a special commemorative lecture to honour one of Australia's distinguished economists, Timothy Coghlan, a pioneer in national income accounting. Appropriately, Colin Clark was invited to give the address. 
The key address, though, was that given by the then President of the Economic Society, Max Corden, on 'Wages, Unemployment and Macroeconomic policy: The Great Debate'. In this, the first presidential address given at the ACE, Corden encapsulated the contentious issue of how to cure unemployment by either real wage restraint or demand stimulation. The Economics Editor of the $A F R$, Paddy McGuinness, believed that the address marked the gradual conversion of the Australian academic economics profession to the proposition that real wages had to fall temporarily if unemployment [was] to be overcome'.$^{10}$

The eighth ACE, held in 1979 at La Trobe University, attracted a relative blaze of media attention, and not just because Colin Clark and Richard Lipsey gave addresses on the relatively new problem of stagflation. ${ }^{11}$ Lipsey reflected on the miserable progress being made to combat it, along with the blight of poor productivity growth and industrial disputation that characterised the seventies. The Conference brochure advertised plenary sessions on economic modelling; the 1979 Federal Budget and state of the economy; Australia and Asia; the Australian manufacturing industry; and two expert surveys on the monetary theory and policy and the balance of payments presented by Michael G. Porter and Jocelyn Horne, respectively. James Perkins spoke on his macro-mix of economic stabilisation, while the Reserve Bank of Australia's Peter Jonson and Bill Norton reported on their institution's economic modelling.

The Conference was the venue for a battle royal between two contending econometric models of the Australian economy: the Impact model of Peter Dixon and Alan Powell versus the Institute Multi Purpose (IMP) model of Peter Brain. For all that, Richard Lipsey noted the general disappointment empirical economists felt about the outcome of econometric research. ${ }^{12}$ In the Conference Oration, Alan Powell dwelt upon technological change, protection and real wages and put to the sword four fallacies then extant in popular Australian economic debate. ${ }^{13}$

From its inception Conference sessions were not always decorous affairs. They were the testing grounds for young economists; but they also gave short shrift to wrong-headed notions. The first evidence of how heated debates could get was in one session of the third ACE in Adelaide where an official from the Federal Department of Labour giving a paper on the rationale of the newly established Prices Justification Tribunal was met with loud dissent. The Tribunal was described as 'a toothless tiger and a diversion from the real cause of the

10 P. McGuinness, 'Wages policy the key issue', AFR, 31 August 1978.

11 Someone collected the press coverage of the Conference for the ESA. There were about 15 cuttings from the Australian press.

12 P. McGuinness, 'Academics, specialists the fashionable path', AFR, 7 September 1979.

13 I. Perkin, 'Lifting the Keynesian grave stone', The Australian, 27 August 1979. 
problem' ${ }^{14}$ At the seventh ACE, at Macquarie University, some were accused of being 'Kindergarten Keynesians' after David Clark and Paddy McGuinness earlier dismissed the Sydney PE movement as 'Kindergarten Marxists'. At the 1979 ACE Conference, two of Australia's greatest economists, Colin Clark and Trevor Swan, clashed after Clark asserted that public servants who administered import controls were corrupt. Swan stormed out of the lecture theatre. ${ }^{15}$ In the ACE held at Monash in 1986, a 'packed' plenary session on 'Economic policy formulation: Policies and Institutions' saw Tom Valentine attack the Federal Treasury for its secrecy and incompetence. The Deputy Secretary of the Treasury, Chris Higgins, described Valentine as 'a monetary expert who still doesn't know what the monetary base is in Australia and how to measure it.'16

The ninth ACE, held at the University of Queensland, was the first to adopt an overarching theme; namely, 'Economic Challenges of the Eighties'. Some 99 papers were presented over three and a half days, with four concurrent sessions running and each presenter given the luxury of 45 minutes. Bill Norton of the Reserve Bank gave a paper on the erosion of economic stability in Australia and overseas. Max Corden and Peter Dixon unveiled their tax-wage discount plan for Australia, which they hoped would rid the economy of persistent stagflation. John Nevile reflected on the parameters of fiscal policy when fighting inflation, while Ian McDonald revealed his research on wages, trade unions and employment. Colin Clark and Noel Fletcher presented a new econometric model of the Australian economy with Keynesian and monetarist features.

At the following ACE, held at the ANU in August 1981, the 1980s resources boom was a favourite topic among the 113 papers presented. The overriding theme was 'Economic Policy Issues of the Eighties'. Craig Emerson (the current Federal Minister for Trade) and Peter Lloyd gave a paper on optimal mineralincome taxation. Bruce Chapman and Ken Clements made their debut by giving papers.

In 1982 ACE went, for the first and only time, to Flinders University. The rather dull Conference theme was 'Policies for Economic and Social Development', with a few of the 71 papers focusing on structural change, new technologies and the economics of communication and information technology.

In 1983, the focus shifted to Hobart, where the overarching theme was of 'Economic Policies for Recovery'. To mark the centenary of Keynes' birth, Groenewegen gave an invited paper on the General Theory. In another evening plenary, Barry Hughes squared off with John Hewson on the Federal Budget.

14 'Tribunal draws economists' scorn', AFR, 25 May 1973.

15 This is more than can be said for another disputant who, in a different Conference, having had enough of one speaker's tirade against Keynesianism, could not find an unlocked door to exit from!

16 M. Stutchbury, 'Treasury comes under attack for role in economic policy', AFR, 27 August 1986. 
Apart from the two evening sessions, the Hobart Conference adopted the strategy of having two plenary sessions per day so that registrants stayed on campus. Bob Gregory and Peter Jonson gave a session on 'The Thirties and the Eighties'. In another plenary, Jonathan Pincus and Mike Porter spoke on 'Regulation and the Role of State Enterprise'. This Conference was also noteworthy because it was the first to reach out to business economists and the business community by having a public-policy symposium.

In 1984, the Western Australian Institute of Technology (now Curtin University) hosted the thirteenth ACE under the grand theme of 'Public Policy for Sustainable Growth'. There was a modest registration of 212 people, 75 per cent of whom came from interstate. This Conference was one of the few occasions when a federal politician, the Minister for Finance, John Dawkins, spoke. There were several papers on stagflation but perhaps the showpiece event was that given by the outgoing Secretary of the Treasury, John Stone, who gave the Shann lecture. It was standing room only for the lecture entitled '1929 and all that' ${ }^{17}$ (A few years later, at the thirtieth ACE, in Perth, another recently retired Treasury Secretary, Ted Evans, gave another Shann address entitled 'Shift in the focus of government economic policies'.) The UNSW hosted the fourteenth ACE, with 335 full registrants. The Conference theme was pure beige: 'Economic Management for Business and Government'. There were to be plenary sessions and two semi-plenary sessions which would cover such issues as libertarian economics; political economy; financial deregulation; tax and social welfare; and wages and industrial relations. There was also a symposium held in downtown Sydney on 'The State of the Profession: Technicians, Theoreticians and Educators — who should rule?'

In 1986, the year of Mr Keating's 'banana republic' speech, Monash University played host to the fifteenth Conference, at its Clayton campus. Despite the campus being 20 kilometres from Melbourne's centre, and having only college accommodation in the vicinity, it attracted 364 registrants and 103 contributed papers. Fred Gruen, whose presidential address was entitled 'Our present discontents', an abridged version of which was later published in the AFR. Two Treasury officers, including Ken Henry, presented the case for a broad-base consumption tax.

In 1987 it was the turn of the Queensland branch to host the Conference, which was held on the Gold Coast. Some 91 papers were presented.

In Australia's bicentennial year there was something regal to match the occasion - an 'Australian Economic Congress'. It was organised by and included the participation of econometricians, agricultural economists, economic historians

17 J. Stone, 1984, '1929 and all that', Quadrant, October, pp. 9-20. 
and, of course, economists. ${ }^{18}$ Of the nearly 1000 registrants, 41 per cent were academics, 35 per cent public servants and 22 per cent business people. Only six per cent of the delegates were from abroad, half of whom were from New Zealand. ${ }^{19}$ The Federal Treasurer, Paul Keating, hosted cocktails in the Great Hall of the newly opened Parliament House. The Prime Minister, Bob Hawke, opened the proceedings with an address that spoke of an Australia undergoing a historic period of reconstruction and reform but still to face its biggest challenge not becoming too dependent on a narrow range of commodity exports. Hawke urged economists to write papers encouraging increased multilateral free trade. Corden spoke about Australian macroeconomic experience, while Groenewegen spoke about 200 years of Australian economics. ${ }^{20}$ John Pitchford questioned the direction of current economic policy with his paper 'Should the current account be a target of macroeconomic policy?'

Michael Stutchbury saw the 1988 congress as prefacing an era of synthesis between Keynesian and neo-classical theories. ${ }^{21}$ David Clark, now a journalist with the $A F R$, was more provocative, deriding many of the papers for their irrelevance. He, like McGuinness, lamented the obsession with quantification and methodology and the general neglect of economic history. He proposed that there be more interplay between university economists and the Treasury, Reserve Bank and the media through the secondment of staff. ${ }^{22}$

The nineteenth ACE was held at the UNSW in September 1990. Some 400 delegates attended and heard papers on issues such as the Accord; the trade deficit; oil; the current account deficit; global warming; financial deregulation; economic rationalism; and tax reform. Some of the best papers were later published in a volume (Johnson et al. 1991), a project which arose from a concern that economy-related issues being researched within Australian universities were underexposed to the wider community. Ironically, the project never kept to its promise of being an annual publication. Much later, the Economic Society asked those giving papers to submit them for possible inclusion in a special Conference issue of the Economic Record, ${ }^{23}$ a practice which has been observed

18 The four societies involved were the Economic Society of Australia, the Econometric Society, the Economic History Society of Australia and New Zealand and the Australian Agricultural Economics Society. 19 J. Macleod to P. Abelson, 8 October 1988, NSW Branch, Economic Society of Australia, UMA.

20 This foreshadowed his 1990 History of Australian Economic Thought, co-authored with Bruce MacFarlane.

21 M. Stutchbury, 'Economists enter era of consensus', AFR, 2 September 1988.

22 D. Clark, 'The village idiots polish their tools under the spreading econometric tree', AFR, 6 September 1988.

23 Many of the keynote addresses by leading international scholars who had attended the 1988 Conference were published in the Economic Record in 1989. 
since the 2002 Conference. The idea of having a Conference volume was again designed to encourage academics to come to the Conference with a paper of publishable quality. ${ }^{24}$

The twenty-third ACE, held in September 1994 at Surfers' Paradise, convened under the theme 'New Directions in Policy; Challenges, Issues and Analysis'. A highpoint of the Conference Dinner was the the evergreen Heinz Arndt being made a Distinguished Fellow of the Economic Society.

The following ACE, in Adelaide, was coupled with the first meeting of the Australian Economics Education Symposium. ${ }^{25}$ The overall theme of the Conference concerned Asian economies and the relations between Australia and Asia. In the plenary sessions, Geoff Harcourt spoke on 'Keynes after 60 years', while Bernie Fraser, then the Governor of the RBA, gave a keynote address entitled 'Central Bank cooperation in the Asian region'. This Conference was also notable for hosting the first Australian sessions of the Society for the Advancement of Socio-Economics (SASE). SASE was essentially a reaction against rampant market ideology and was linked to Amatai Etzioni. Eventually, SASE would cluster under the Society for Heterodox Economics, which Peter Kriesler established in 2001.

The next landmark Conference was perhaps in 1996 when the ANU hosted 450 registrants attending either the Conference or symposium. This Conference was noteworthy because it was one of the first managed by professional organisers.

The 1997 Conference, in Hobart, adopted the rather banal theme of 'Policy Challenges of the New Century'. The following year, at the University of Sydney, there were plenary sessions on unemployment, social welfare and income redistribution; tax reform; macroeconomic policy in a global setting; and labour market reform. Among the key themes at the 1999 Conference, at Latrobe University, were recovery from the Asian economic crisis; the economics of education; experimental economics; and the economics of addiction.

Attendance at the thirtieth ACE, held at UWA in September 2001, was affected by the fallout from the September 11 terrorist atrocities in New York and by the collapse of Ansett Airlines. Nonetheless, some 275 delegates made it to Nedlands and discussed such topics as whether Australia was an old or a new economy. ${ }^{26}$

\footnotetext{
24 The first special issue of the Economic Record, entitled 'Selected Papers from the National Conference of Economists', was edited by M. K. Lewis, M. P. Shanahan, R. Bareto and P. D'arcy.

25 The 14 papers presented at the symposium were later published in M. P. Shanahan and J. Cowie (eds) Australian Economics Education Symposium Proceedings. This group of economists now meet separately under the banner of the Australian Teaching Economics Conference, and recently held their 15th Annual Conference. 26 UWA Department of Economics 2001 Annual Report: 26-7.
} 
The syllabus of the following ACE, which took place in a hotel at Glenelg Beach in Adelaide in 2002, focused upon the new agenda of the new millennium, namely: the electricity market; the economics of wine; the supply and use of water; fiscal equalisation; and the Japanese economy. The principal keynote speaker was David Card, whose research with Alan Kruger called into question the assumed negative correlation between minimum wages and employment. The accompanying public-policy symposium looked at the economic and business implications of ageing baby-boomers.

The 2003 Conference was hosted by the ACT Branch of the Society in association with the Economic History Society of Australia and New Zealand. The publicpolicy symposium was on 'The Role of Economics and Public Policy' and featured the heads of Treasury, the Department of Prime Minister and Cabinet, the Productivity Commission and the Australian Competition and Consumer Commission.

In an appraisal of the following year's Conference, at Sydney University, Neville Norman, then President of the Victoria Branch of the Society, approved of the papers and the quality of the presentations, commenting that 'even theoretical papers in advanced mode had something for the more general economist'. He also noted that some of the 'superstars' had made a 'huge effort' to encourage younger economists with their comments in the general sessions. ${ }^{27}$

When in the following year the Tasmanian branch had to withdraw from its hosting duties at short notice, Melbourne stepped into the breach and produced an outstanding Conference. The agenda revolved around topics such as freetrade agreements; unemployment in Australia and other nations; labour market reform; the economic status of indigenous Australians; superannuation; the control of illicit drugs; water pricing; and taxation. These issues, along with climate change and well-being, would dominate subsequent Conferences. In 2007 the plenary sessions in Adelaide focused on the economics of happiness; corruption; skilled labour migration; emissions trading; water pricing; and consumption and taxes of drugs.

\section{Conference Dinner and ancillary activities}

Paul Samuelson was fond of saying that the favourite topic of conversation among economists was other economists. The Conference Dinner has proved itself an excellent opportunity for economists to network and gossip. Like the Conference itself, it assumed particular resonance before the revolutions in communication technology. Presentations at the Conference Dinner include a prize for the best article in The Economic Record, an award for the best young 
economist under 40, as well as an honorary fellow award. Conference Dinners usually featured an eminent after-dinner speaker. Award winners and honour awardees were also expected to make speeches. There is no record, though, of the wise utterances and reflections having ever been recorded. As the report of the first Conference put it: 'The success of such a conference is not only in terms of number and quality of the papers, or the number of people attending, but by the formal and informal gatherings of people. ${ }^{28}$

In 1974, the Conference Dinner was made somewhat disagreeable when the afterdinner speaker, an animated Bob Hawke, then President of the ACTU, rebuked his hosts for perpetrating the mathematisation of the discipline. This was not reported in the press. ${ }^{29}$ In the 1978 Conference at Macquarie the 'modest farmer' and later 'modest member of Parliament' Bert Kelly, an ardent free-trader, was the after-dinner speaker. In 1983, the speaker was the Tasmanian Governor, Sir James Plimsoll, who initially trained as an economist. He established the precedent that whenever the ACE was held in Hobart there would be a cocktail reception at Government House.

The 1987 Conference Dinner was noteworthy because it was preceded by the awarding of the first Distinguished Fellow of the Economic Society of Australia. The first recipients were Colin Clark and Trevor Swan; two economists whom many in Australia fondly thought were contenders for the Nobel Prize in economics. Bob Hawke presented the awards before giving the after-dinner speech. Unfortunately, illness prevented Colin Clark from appearing to receive his award but this saved the ceremony from potential embarrassment as he had been Hawke's somewhat disgruntled supervisor at Oxford. ${ }^{30}$

In 1992 economists were gently mocked in a more humorous vein by the Melbourne lawyer-turned-comedian, Campbell McComas, who was adept at portraying fictional characters to suit the audiences he was entertaining. It was he who referred to gatherings such as the ACE as a 'recession of economists'. The Adelaide Conference in 1995 featured the Federal Treasurer Peter Costello as after-dinner speaker. John Kerin, the last Federal Treasurer in the Hawke Government, did the honours at the 1991 ACE in Hobart.

Astonishingly, in the first decade of the ACE, the last day of proceedings was assigned to giving registrants a tour of the environs. This was optional, of course, with some registrants opting to return home. In those days, Conference

\footnotetext{
28 1969/70 Annual Report of the Victorian Branch of the ESA: 5; ESA Papers, UMA.

29 Communication with two Australian economists, 12 April 2011.

30 Bob Hawke has appeared at more ACE functions than any other Australian politician. Peter Yule (2011) who is writing a history of the ANU College of Business and Economics, has uncovered that in 1958 Heinz Arndt, then at the Canberra University College, offered a job to Hawke as a lecturer in industrial relations. Hawke opted for the position of research officer at the ACTU instead. P. Yule 'Hieser, Hawke and Harsanyi', The Margin 3: 22-3.
} 
registration was done manually, and a whole afternoon might be allocated to this task. At the 1977 ACE in Hobart, a visit to Port Arthur was included in the Conference proceedings. As the Conferences became more professional, however, the contributed papers and plenary sessions were gradually compressed into three days, rather than being week-long affairs. The three-day time period resembled that of the AEA meetings, but the Economic Society of Australia has never contemplated holding proceedings over a weekend in what is still the land of the long weekend.

One area of perennial concern for the Economic Society was how to ensure that the ACE had some forums geared towards 'downtown' economists and to the media. Thus, since the 1983 Conference, organisers have included a business symposium (sometimes dubbed a 'public-policy symposium') which could be held at the Conference or at a different location. Unlike the actual Conference of economists, the symposium always has a theme which is rigidly enforced. As public-sector and market economists assumed a growing proportion of membership of the Economic Society, it was felt that Conferences needed to be held in more convivial locations than the groves of academe. Sometimes the public symposium ran alongside the contributed-paper session, as happened in the 1992 ACE held at Melbourne University. At the 1986 ACE at Monash there was, for the first time, the attraction of book publishers showing off their wares, as well as a display of 'micro computer' software applications.

\section{Venue, timing and pricing}

In its first 10 years of life, the ACE Conferences were held exclusively at university campuses, despite the logistical difficulties involved in getting the registrants there and accommodating them in student quarters. Today, universities with front-rank economic departments often host Conferences at convention centres, hotels or at an integrated facility, as opposed to holding them on campus. Offcampus locations can present fewer logistical problems, and offer increased media exposure. For this reason, a number of universities with leading economics departments, including James Cook University, Deakin University, RMIT University, the University of Newcastle, UTS, the University of New England, ${ }^{31}$ the University of Western Sydney, the University of Wollongong, and the University of South Australia, have never hosted or sponsored an ACE. ${ }^{32}$

The first of the Conferences to be held off campus was hosted by the Queensland branch of the Society in 1987, when ivory towers gave way to the concrete towers of the Gold Coast. The Holiday Inn in Surfers Paradise had a banner

31 In August 1974 the Central Council of the Economic Society agreed to hold a future Conference of Economists at UNE following a proposal to that end lodged by Professor Drake. ESA papers, UMA.

32 Victoria University in Melbourne will host the ACE in 2012. 
over its entrance proclaiming 'Welcome Economists!' 'Where else,' David Clark mischievously asked, 'would economists be received so charitably?' He supported the idea, however, of the off-campus Conference. Despite the glitzy locale, the attendance suggested it was a success and the Queensland branch, in league with its universities, would nominate the Gold Coast as their preferred location from there on. However, in 2010 the Central Council of the Economic Society resolved that university campuses would be the preferred location for future Conferences, reflecting a sense that the academic atmosphere of the Conference is diminished in other venues.

The timing of ACE has been problematical. Initially, the Conferences were held in May; then it was decided that August or September was better because there were common breaks from teaching for Australian academics (some Australian universities ran on semesters, others on terms). In 2000 the ACE held on the Gold Coast was switched to July because the Sydney Olympics were scheduled for September. It has been often argued that holding the ACE in the Australian spring made it difficult for Conference organisers to attract guest speakers to come down under because it was term time in Europe and North America. The Central Council recently resolved to switch the ACE to a mid-year date. Another problem with timing was ensuring Australia's premier economic Conference fell at a time when there were no rival conferences. For instance, while the 1986 ACE was under way at Monash, econometricians were hosting their own conference at the University of Melbourne. In 1981 Max Corden prompted the Economic Society to give the ACE early publicity so to avoid clashes with other conferences. It was argued that the 1980 ACE had been affected by ANZAAS Golden Jubilee Congress, held three months earlier in the same place, where some 30 economics papers were presented. ${ }^{33}$

In recent years there have been concerns raised about the standard registration fees (see Table 1) for attending the ACE, especially in the sense that they have been outpacing the rate of inflation and, therefore, affecting attendance.

Table 1: The Australian Conference of Economists, 1970-2011

\begin{tabular}{llllll}
\hline $\begin{array}{l}\text { Conference } \\
\text { Number }\end{array}$ & $\begin{array}{l}\text { Host } \\
\text { University }\end{array}$ & $\begin{array}{l}\text { Host } \\
\text { Branch }\end{array}$ & Conference Date & $\begin{array}{l}\text { Number of } \\
\text { Papers }\end{array}$ & $\begin{array}{l}\text { Attendance } \\
\text { Fees** }\end{array}$ \\
\hline 1 & Melbourne & VIC & May 1970 & 36 & $\$ 9$ \\
2 & Sydney & NSW & August 1971 & 30 & \\
3 & Adelaide & SA & August 1973 & 60 & $\$ 10$ \\
4 & ACT & ACT & August 1974 & 45 & $\$ 16$ \\
5 & UO & OLD & August 1975 & 80 & $\$ 17$ \\
6 & UTAS & TAS & May 1977 & 87 & $\$ 30$
\end{tabular}

33 Minutes of the Central Council meeting, 28 August 1981, Economic Society of Australia papers, UMA. 


\begin{tabular}{|c|c|c|c|c|c|}
\hline $\begin{array}{l}\text { Conference } \\
\text { Number }\end{array}$ & $\begin{array}{l}\text { Host } \\
\text { University }\end{array}$ & $\begin{array}{l}\text { Host } \\
\text { Branch }\end{array}$ & Conference Date & $\begin{array}{l}\text { Number of } \\
\text { Papers }\end{array}$ & $\begin{array}{l}\text { Attendance } \\
\text { Fees * * }\end{array}$ \\
\hline 7 & Macquarie & NSW & August 1978 & 99 & $\$ 40$ \\
\hline 8 & La Trobe & VIC & August 1979 & 115 & $\$ 45$ \\
\hline 9 & UO & QLD & August 1980 & 99 & $\$ 50$ \\
\hline 10 & ANU & ACT & August 1981 & 113 & \\
\hline 11 & Flinders & SA & August 1982 & 71 & \\
\hline 12 & UTAS & TAS & August 1983 & 80 & $\$ 90$ \\
\hline 13 & WAIT/Curtin & WA & August 1984 & 70 & \\
\hline 14 & UNSW & NSW & May 1985 & 91 & $\$ 80$ \\
\hline 15 & Monash & VIC & August 1986 & 103 & \\
\hline 16 & Surfers & QLD & August 1987 & 91 & \\
\hline 17 & ANU & ACT & August 1988 & 113 & $\$ 250$ \\
\hline 18 & Adelaide & SA & July 1989 & & \\
\hline 19 & UNSW & NSW & September 1990 & 120 & \\
\hline 20 & UTAS & TAS & September 1991 & & \\
\hline 21 & Melbourne & VIC & July 1992 & 173 & \\
\hline 22 & Murdoch & WA & September 1993 & $200 *$ & $\$ 250$ \\
\hline 23 & & QLD & September 1994 & $188^{*}$ & $\$ 310$ \\
\hline 24 & Adelaide & SA & September 1995 & & $\$ 450$ \\
\hline 25 & ANU & ACT & September 1996 & $204 *$ & $\$ 450$ \\
\hline 26 & UTAS & TAS & September 1997 & 168 & $\$ 450$ \\
\hline 27 & Sydney & NSW & September 1998 & & $\$ 500$ \\
\hline 28 & La Trobe & VIC & September 1999 & & $\$ 500$ \\
\hline 29 & & QLD & July 2000 & 77 & $\$ 545$ \\
\hline 30/ACE01 & UWA & WA & September 2001 & 190 & \\
\hline 31/ACEO2 & Adelaide & SA & September 2002 & 207 & \\
\hline 32/ACEO3 & ACT/ANU & ACT & September 2003 & $181 *$ & $\$ 620$ \\
\hline 33/ACEO4 & Sydney & NSW & September 2004 & 148 & \\
\hline 34/ACE05 & Melbourne & VIC & September 2005 & 187 & $\$ 600$ \\
\hline 35/ACEO6 & Curtin & WA & September 2006 & 153 & \\
\hline 36/ACEO7 & & TAS & September 2007 & 145 & $\$ 675$ \\
\hline 37/ACE08 & & QLD & September 2008 & 138 & $\$ 755$ \\
\hline 38/ACEO9 & Adelaide & SA & September 2009 & 145 & $\$ 700$ \\
\hline 39/ACE10 & Macquarie & NSW & September 2010 & 162 & $\$ 800$ \\
\hline 40/ACE11 & ACT/ANU & ACT & July 2011 & 259 & $\$ 650$ \\
\hline
\end{tabular}

* Includes public symposium papers.

** The figures cited are the standard registration fees for Economic Society members.

Sources: Compiled from a number of ACE brochures and Economic Society Victorian Branch papers, University of Melbourne Archives and Economic Society NSW Branch, courtesy of Jane Oldroyd.

In 1970 fees were a modest $\$ 9$ but by 2008 they had soared to $\$ 755$, which meant that, with airfares and accommodation, interstate delegates were looking 
at a figure greater than $\$ 1500$. The considerable jump in fees between the years 1985 and the mid-1990s presumably reflected the fact that during this period the Conference arrangements were assumed by professional event organizers. Registration fees have risen 800 per cent in real terms since 1970. Since 1996, however, the rise has been more modest. Since the outset, fee discounts have been offered to Society members and to students. Later there was a discount offered to those who registered early. The Conference Dinner has often been cross-subsidised.

\section{International speakers}

By the late eighties there was an expectation that the Conference hosts would recruit at least three internationally renowned speakers. In the first decade of Conferences, however, there were relatively few international drawcards (David Laidler 1977, Richard Lipsey 1979, William Poole 1980). From 1980 onwards, organisers began to seek major international economists as keynote speakers. In 1985 Dietrich Fausten, convenor of the ACE at Monash University, proposed that the state branch hosting the Conference bring out eminent scholars to the Conference and be responsible for the costs. ${ }^{34}$ Even with the power of the internet and virtual technologies, nothing beats having speakers present in the flesh. (The ESA-organised tour of Joe Stiglitz in 2010 surely confirmed this.) It was believed that the presence of international speakers would generate interest. While there were problems attracting international speakers, they did come. The honorarium for international speakers in 1988 was, on occasion, \$3000; 10 years later, it could be as high as $\$ 10000$. Yet some international speakers have continued to donate their time gratis. The 1988 Australian Economic Congress commanded an international guest list of 14 eminent scholars.

Table 2 lists some of the international speakers invited to address ACE.

Table 2: Invited International Speakers at the Australian Conference of Economists, 1970-2010

\begin{tabular}{lll}
\hline $\begin{array}{l}\text { Conference } \\
\text { Year }\end{array}$ & $\begin{array}{l}\text { Host } \\
\text { University }\end{array}$ & Invited International Speakers \\
\hline 1979 & La Trobe & $\begin{array}{l}\text { Christopher Pissarides, John Taylor, Steven Turnovsky, Tun } \\
\text { Thin }\end{array}$ \\
1981 & ANU & $\begin{array}{l}\text { Robert Eisner, } \\
1982\end{array}$ \\
1984 & Flinders & Michael Artis \\
1986 & Monash & Al Harberger, Avinash Dixit, Anne Kruegar, Rod Dean \\
1987 & Surfers & W. Isard, D. Smyth
\end{tabular}

34 Minutes of Victorian branch of the ESA, July 1985, UMA. 


\begin{tabular}{|c|c|c|}
\hline $\begin{array}{l}\text { Conference } \\
\text { Year }\end{array}$ & $\begin{array}{l}\text { Host } \\
\text { University }\end{array}$ & Invited International Speakers \\
\hline 1988 & ANU & $\begin{array}{l}\text { Tony Atkinson, Fred Bergsten, Alan Blinder, Angus Deaton, } \\
\text { John B Taylor, Granger Joe Stiglitz, Robert Gordon, Jurgen } \\
\text { Donges, Jean-Jacques Laffont, Edward Learner, William } \\
\text { Parker, Hashem Pesaran, Ja Hausman, Jeffrey Williamson }\end{array}$ \\
\hline 1990 & UNSW & Ed Nell, Wilfred Beckerman, Shaun Hargraves Heap \\
\hline 1992 & Melbourne & Charles Goodhart \\
\hline 1995 & Adelaide & John Siegfried, William Becker, Jim O’Neil \\
\hline 1996 & ANU & $\begin{array}{l}\text { Henry Aarons, Jagdish Bhagwati, Jonathan Eaton, David } \\
\text { Greenaway, Gale Johnson, Alan Maynard, William Nordhaus, } \\
\text { Don Brash, Cliff Winston }\end{array}$ \\
\hline 1997 & UTAS & William Baumol \\
\hline 1998 & Sydney & Ken Arrow, Anne Kruegar, Jean-Jacques Laffont \\
\hline 1999 & La Trobe & $\begin{array}{l}\text { Chris Pissarides, John Taylor, Stephen Turnovsky, David } \\
\text { Greenaway }\end{array}$ \\
\hline 2000 & & $\begin{array}{l}\text { Alan Kreuger, Robert Gordon, Gary Becker, Stan Metcalfe, } \\
\text { Peter Sinclair, Art Goldsmith Chris Snyder, Jacob Frenkel }\end{array}$ \\
\hline 2002 & Adelaide & David Card, E. Barbier, Bob Nobay, Albert Breton \\
\hline 2003 & $\mathrm{ACT} / \mathrm{ANU}$ & $\begin{array}{l}\text { Paul Ormerod, Richard Freeman, Deidre McCloskey, Larry } \\
\text { Meyer, Peter Neary, Jeffrey Williamson, Stanley Fischer }\end{array}$ \\
\hline 2004 & Sydney & Robert Hall, Partha Dasgupta, Robert Frank, Paul Milgrom \\
\hline 2005 & Melbourne & $\begin{array}{l}\text { James Galbraith, Olivier Blanchard, John Sutton, James } \\
\text { Robinson }\end{array}$ \\
\hline 2006 & Curtin & Arjo Klamer, George Mailath, Mark Killingsworth \\
\hline 2007 & & Anne Krueger, Richard Blundell, Dilip Mookherjee \\
\hline 2008 & & Adonis Yatchen, Charles Perrings, Kathryn Dominguez \\
\hline 2009 & Adelaide & $\begin{array}{l}\text { Edward Lazear, Lorraine Dearden, Lin Zhou, Robert Shimer, } \\
\text { Lee Ohanian, Brian Copeland, Orley Ashenfelter }\end{array}$ \\
\hline 2010 & Macquarie & $\begin{array}{l}\text { Peter A. Diamond, Michael Keane, Carol Walsh and Linda } \\
\text { Tesar }\end{array}$ \\
\hline 2011 & ANU & $\begin{array}{l}\text { Hal Varian, Glenn R. Hubbard, Larry lannaccone, Stephen D. } \\
\text { Williamson, Peter Klenow }\end{array}$ \\
\hline
\end{tabular}

\section{Media}

The Australian media have taken a somewhat schizoid view of the ACE. At times they would provide good press coverage, while at others they simply decided not to show up. One of the reasons for this in the early years was perhaps best summed up by Paddy McGuinness in 1979. After attending the La Trobe Conference that year, an event which had been advertised in the AFR, McGuinness noted that contemporary concerns - inflation, unemployment and energy policy - were not major topics of interest amongst presenters and that Conference proceedings were so theoretically obscure as to make them useless for the purposes of contemporary policy debate. There was a delay, he 
suggested, in academic economists turning to these concerns. ${ }^{35}$ His colleague David Clark took an even more scathing attitude. 'Economic conferences', he opined, 'are usually just curriculum vitae padding opportunities for academics and an excuse to catch up on the latest gossip at taxpayer expense. ${ }^{36}$ This is why private sector economists stay away from them in droves. ${ }^{37}$ However, the Conferences of the 1980s made for good copy, as McGuinness, Clark and Michael Stutchbury regularly attended the ACE. The 1986 ACE, for instance, was featured in five newspaper articles. Stutchbury reported on some of the more interesting contributions, remarking that for all the output, 'None of the competing economic paradigms offer a solution to Australia's balance of payments crisis. ${ }^{38}$ Clark also reported on Ian Castles' paper entitled 'Fact and fantasies about Bureaucracy'. The paper argued against Donald Horne and Hugh Stretton's criticisms of the economic policy departments, particularly Treasury. ${ }^{39}$ In contrast, there was no newspaper coverage of the 1991 or 1992 ACE, and it has been somewhat sporadic ever since.

\section{Organisation and process}

Organisationally, the Central Council of the Economic Society adopted the principle that each of the seven Australian branches take it in turn to host the Conference, and be responsible for all administrative and financial arrangements. In this scheme of things, Central Council would advance a sum to the state branch organising the Conference and subsequently share in any profit. In 1971, for instance, the NSW Branch repaid its loan of $\$ 200$ to the Central Council, along with the sum of $\$ 175$ as its share of the profit. ${ }^{40}$ The very first Conference made a profit of $\$ 100$. Since then the ACE has always been profitable and branches have been reluctant to pass up an opportunity of a septennial windfall. Up until 2003, an annual appointment system operated before an amenable rotation system was implemented under the auspices of Neville Norman. After 40 Conferences, as Table 1 shows, the share going to all seven branches is almost uniform, with NSW hosting seven and the rest hosting six apiece, except for the Tasmanian and Western Australian branches which have held five and four Conferences respectively.

\footnotetext{
35 P. McGuinness, 'Australia grapples with inflation, unemployment... while La Trobe Conference deals with yesterday's issues', AFR, 11 September 1979.

36 This might have been the inspiration for the statement by an unnamed ANU professor against Clark (which Clark himself caught wind of) 'That Clark has done more to harm the public standing of academic economists than anyone else in Australian history'; cited from 'Wanted: ambidextrous economists', AFR, 30 September 1991.

37 'Privatising Treasury', AFR, 28 August 1986.

38 M. Stutchbury, 'Conference manages to highlight the abysmal forecasting record of economists', AFR, 27 August 1986.

39 D. Clark, 'Horne, Stretton views accused of being "grotesque" images'; and M. Stutchbury, 'Treasury comes under attack for role in economic policy', AFR, 27 August 1986.

40 H. Bell, Circular to Branches and Central Council, no.1 1972, ESA Papers, UMA.
} 
While the very first Conference required only six months to prepare, Conferences today usually need 18 months to arrange speakers, venues and logistics. The Central Council has established a convention where Conference organisers could draw upon the wisdom and experience of the immediate past Conference. ${ }^{41}$ Additionally, a report on the preceding year's Conference has been presented for the purview of the Central Council.

Strangely, despite the outstanding success of the first few Conferences, there were no Conferences in 1972 or 1976. What happened in 1972 is unknown, but the regular ANZAAS meeting went ahead, with some economists presenting. There had been a last-minute attempt in November 1975 to commission a Conference for 1976 but a lack of time and unfavourable finances meant that the W.A. Branch could not deliver. ${ }^{42}$ There was, however, an ANZAAS Conference, with the economics section being arranged by Gerald Firth from the University of Tasmania.

\section{Does life really begin at $\mathbf{4 0}$ for the ACE?}

Until the 1980s the ACE was the grand premier show in town as far as Australian economists were concerned. In 1972 there were concerns expressed over whether the Australian economics profession could sustain a high-quality conference at yearly intervals. However, it was pointed out that in 1971 the profession had been able to hold three conferences of high quality: ANZAAS in May; the Monash econometrics conference in early August; and the second ACE later that month. ${ }^{43}$ That busy year, however, pales into insignificance compared with today. Now ACE faces a plurality of specialist conferences and workshops which must have some adverse impact on numbers attending its Conference. A crowding-out phenomenon is at play. Before ACE40 began, in Australia in 2011 there had already been a host of specialist conferences/workshops, both domestic and international, for local economists to attend. This is a perfectly natural development and reflects well on the depth and plurality of the Australian economics profession.

However these developments pose danger to the status of the ACE. The econometricians now have their own conference, and some feel that this development has lowered the technical pedigree of the ACE. Some of these other conferences are regarded by practitioners as a must-attend, and young

\footnotetext{
41 In 1976 the former Secretary of the NSW Branch and convenor of the second ACE, Frank Collins, produced a handbook on the original intent of the Conference. Neville Norman would prepare another operational manual in 2007, outlining procedural matters.

42 B. Parmenter to R. H. Scott, 17 November 1975, ESA Archives, UMA.

43 H. Bell Circular to Branches and Central Council No, 1, 1972, ESA Papers UMA.
} 
and aspiring scholars swear to the benefits of attending them — in particular, the annual Ph.D Conference in Economics and Business held alternately at UWA or the ANU. Most of these specialist conferences have a more rigorous referring process than the ACE, often with single, rather than concurrent, sessions. Consequently, those giving papers there can expect to have both high-quality feedback and networking opportunities. This counts for something when the race is on to publish in high-ranking journals. It also counts if academics have limited funding and elect to go to the conference which offers the greatest value to their individual areas of research. Another dynamic is that the faculty at leading economic departments within Australian universities are increasingly internationalised, and thus have no particular interest in or loyalty to the Economic Society (Millmow 2010).

The Excellence in Research Australia process and the shadow system that now follows in its wake can also be expected to exert some detrimental influence upon conference selection. Conference funding in the better-ranked economic departments will be channelled to high-ranking publishers, who may well prefer specialist conferences over ACE. There is additionally the strategy of concentrating effort on particular 'research codes' and this, in turn, will influence the sort of papers that are presented in future. There may be a narrowing of fields of research than are usually available at ACE, or the fact that the papers being presented are likely to be geared towards publication in high-ranking journals will mean that while the technical quality will be high they will be less policy-orientated and possibly armed with North American data. The business economists have, for the most part, gone off to their own forecasting conferences and, interestingly, these tend to attract the officials from both the RBA and the Treasury to address them - again this is quite understandable.

Nevertheless, the power of instantaneous communication and blogging has not reduced the value and attraction of an interactive conference, of seeing presentations by leading scholars in the flesh.

In a paper to the Central Council of the ESA, Jonathan Pincus suggested that the ACE would be given even greater international profile if the date were changed to mid year so that more international scholars from the northern hemisphere could attend. ${ }^{44}$ While this is now in place, the fact remains that a trip from Europe is, logistically, still an ordeal. Moreover, holding a Conference in mid winter might deter attendance. Pincus, however, went further, wanting to imitate the Allied Social Sciences Association (ASSA) in the United States by encouraging all economists, whatever their specialisation, to meet under the one roof, and suggesting this occur for 2015. However, the different field societies

44 J. Pincus, 'Creating an Annual Meeting of all economic and related groups, to be hosted by the Economic Society of Australia starting 2015', 15 September 2008. 
might reject the idea of a grand conference because each field conference is strongly linked with its own unique identity. A compromise, of course, would be to expand the size of the ACE by having dedicated sessions for the history of economic thought, economic history, agricultural and resource economics, health economics, and so on. This has occasionally been done but no society would be prepared to throw in their lot entirely with the ACE. Moreover, Pincus reminds us that a somewhat similar body to ASSA in Australia was ANZAAS, which has become moribund, with the last congress taking place in 1997. Could its demise portend the future of ACE? Pincus is probably right in lamenting that the federal structure of the Economic Society, with each state entitled to conduct a Conference every sixth or seventh year, impairs the Society from running successful and grander-scale Conferences. It is apparent, for instance, that Conferences on the eastern seaboard tend to be better attended than those held elsewhere.

ACE will survive, not least because of its use of conference managers, but also on account of the policy of continuous auditing and long lead times in planning future Conferences. It will also prosper because despite the attraction of more specialist conferences the ACE, like the Australian economics profession, still punches above its weight.

\section{References}

Johnson, M. A., Kriesler, P. and Owen, A. D. 1991, Contemporary Issues in Australian Economics, Macmillan.

Scott, R. H. 1990, The Economic Society of Australia: Its history 1925-1985.

Millmow, A. J. 2010, 'The Changing Sociology of the Australian Academic Economics Profession', Economic Papers 29(1): 87-95. 